EIS 13/2019

Internet Use for Shopping in Latvia: Findings by Recent Survey

Submitted 06/2019

Accepted for publication 10/2019

Abstract

Introduction

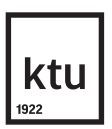

European Integration Studies No. 13 / 2019, pp. 108-116 doi.org/10.5755/j01.eis.0.13.23496

\section{Internet Use for Shopping in Latvia: Findings by Recent Survey}

Biruta Sloka, University of Latvia

Kate Čipāne, University of Latvia

Sergejs Volvenkins, iMarketing, Latvia

$\Gamma$

Crossef http://dx.doi.org/10.5755/j01.eis.0.13.23496

Recent developments of internet applications and increase in application of various information technologies have supported fast development of internet shopping worldwide and also important topics for academic researchers. Aim of the research: check findings of recent preferences by customers on internet shops and factors for internet shop choice, different aspects on internet shopping and comparisons with academic research results in other countries. Tasks: scientific findings studies and empirical investigations on customer preferences and determining factors for choice of different factors in internet shopping. Research methods used: recent scientific publications studies, studies of statistics on internet shopping development, survey on internet shop choice and on internet shopping in Latvia realised at the end of 2017 and beginning of 2018. Survey was developed and realised in co-operation with company specialising on internet marketing: iMarketing, University of Latvia and Chamber of Trade and Commerce of Latvia. Respondents were selected randomly in assistance of Chamber of Trade and Commerce of Latvia. Survey was filled in by 2530 respondents. For many aspects in evaluation of opinion of respondents it was used evaluation scale 1 - 10, where evaluation by 1 was - do not agree with the statement; 10 - fully agree with the statement. For data analysis there were used indicators of descriptive statistics: indicators of central tendency or location (arithmetic mean, mode, median, quartiles), indicators of variability (variance, standard deviation, standard error of mean), cross - tabulations, statistical tests of hypotheses, multivariate analyse methods: regression and correlation analysis, analysis of variance (ANOVA), factor analysis and other data analysis methods. Main results and findings of the study, theoretical and practical implications of the work: response rate of respondents was very high in comparison with other surveys; respondents have expressed also their suggestions for internet shopping improvements; respondents have indicated the most attractive internet shops by their views. Main conclusions: increase in internet shopping in Latvia is not increasing so fast as in other countries, customers use also mobile devices for shopping on internet.

KEYWORDS: internet marketing; factors influencing of internet shop choice; preferences on shopping in internet; survey

Recent developments of internet applications and increase in application of various information technologies have supported fast development of internet shopping worldwide. Internet shopping creates convenience for customers, bigger selection of goods and services for customers from one side, but create also several challenges and additional opportunities for companies as well as some problems for companies and customers from other side. Active researches on different aspects on internet shopping are performed by companies, academic researchers and in co-operation of businesspersons and academic researchers to use expertise as efficient as possible. 
Aim of the research is to check findings of recent preferences by customers on internet shops and factors for internet shop choice, different aspects on internet shopping and comparisons with academic research results in other countries. The tasks are:

1 explore customer preferences and habits on internet shops worldwide and how they influence internet shop choice;

2 analyse data on Internet usage habits of the internet in Latvia;

3 analyse consumers' shopping preferences on the internet.

Research methods used in the research are analysis of scientific publications and previously conducted research results; analysis of survey realised in Latvia at the end of 2017 and beginning of 2018 on internet shopping in co-operation with company iMarketing, University of Latvia and Chamber of Trade and Commerce of Latvia. For many aspects in evaluation of opinion of respondents it was used evaluation scale $1-10$, where do not agree with the statement; 10 fully agree with statement. For data analysis there were used indicators of descriptive statistics, cross - tabulations, statistical tests of hypotheses, correlation analysis, analysis of variance (ANOVA) and other data analysis methods.

Main results of the research reveal that e-commerce in Latvia is not increasing as fast as in other countries; customers mainly use internet for checking e-mail, making payments and searching for information, not for shopping.

The internet has changed the way how information is accessed and shared between people as it is concluded by Anasi, Lawas \& Paul-Ozieh (2018).

Internet is used for a lot of purposes, for example Castellacci and Vinas-Bardolet have studied whether use of internet for job foster employees' job satisfaction. Results revealed that internet technologies really enhance job satisfaction, because employees can access information, data, communicate among themselves and also create new activities, but it was also indicated that those who have higher income and educational level benefit more than those who work in professions weakly related to ICTs activities.

Study in Nigeria was researching community pharmacist use of internet as health information resource and results reveal that the main challenges which hinder the use of internet is low power of supply and lack of money for purchases of internet facilities. Also gender, age, level of educations and number of years in professional practice have significant relative contribution on frequency of internet use among community pharmacist in Nigeria which were stressed by researchers Anasi, Lawas \& Paul-Ozieh (2018).

Study in Sudan was researching internet and e-mail use among Sudanese librarians and results revealed that the main purposes of internet use are chat sessions, checking e-mails and surfing professional sites. This researched proved that the level of English language significantly affects the level of use of the internet applications in library services concluded by Mudawi (2005).

Another study was exploring internet and Facebook usage on student's academic distraction, as more and more people use social networks daily. Students are exposed to the increasing volume of information more than ever before, because of availability and varied usage of internet and the study revealed that there is positive relationship between increase in frequency of Internet usage for entertainment per day and the increase in academic distraction by Feng et.al. (2019).

Aspects of the association between financial literacy and problematic internet shopping in a multinational sample indicating several problems and challenmges buy Lam \& Lam (2017) have concluded that results of research in three continents showed that enhancement of financial literacy in the general population, particularly among young people have a positive effect on the 
occurrence of problems in internet shopping. Researchers in many countries have sated question: internet or store which approach is more acceptabl;e for most of customers and dtermening trendes and fashings of their developement - an ethnographic study of consumers' internet and storebased grocery shopping practices by Elms, de Kervenoael \& Hallsworth (2016) by ethnographic case studies were presented of two consumers' internet and store-based shopping practices, and researchers ahve analysed and investinaged how these intersect with their everyday lives, using data generated from multiple, complementary methods over an eighteen-month period have indicated several important factors affecting the consumers decisions including inflence of marketing.

Researchers investigate how consumers in different countries behave in internet-shopping as it is getting more and more business without borders - a profile of the Internet shoppers: evidence from nine countries were studied by Lim \& Cham (2015) who have concluded that there is still much work to be done in the research area of Internet shopper profiles. Due to globalization, it is important to explore global similarities and differences on a regional basis-between and within and Lim \& Cham (2015) hope that their research will contribute to effective online marketing strategies across the globe.

Intelligent decision-making of online shopping behavior based on internet of things aspects are on research agenda by Fu et al. (2019) concluding among other important aspects also that consumers rely more on safety perception reviews to make purchasing decisions when purchasing high contact degree items. Researchers have performed their research in exploring why people spend more time shopping online than in offline stores (Chiao et al. 2019) and have suggested practical recommendations for possible use in practice.

Use of internet has been widely researched topic in a lot of countries. Study in Pakistan has researched gender disparities in the use of internet among graduate students and the results show that there are differences between men and women, for example, that women use internet mostly for entertainment, social interaction and communication, but men are more experienced and skilled than women, because more men possessed personal computers.as it is indicated by Ahmad, Rafiq \& Ahmad: (2018).

Researchers group Fortson, et. al. (2007) unlike other studies has found that there are no significant differences between men and women on the mean amount of time accessing the Internet every day. Malamud, et. al. (2019) have studied impact of internet access at home for children in Peru and it was revealed that providing children with access to computers and internet at home close together with some training help improve children's digital skills and fill the gap between those who have computer and internet at home and those who have not.

Internet shopping is developing very fast world-wide - in some countries faster in some slower but group of researchers Sharma et. Al. (2019) are asking foresight for online shopping behavior - they have performed a study of attribution of several aspects for "what next syndrome" - researchers have suggested some practical next steps for marketing specialists as well as for customers.

Academic researchers are making their investigations for understanding shopping routes of customers of offline purchasers with special attention on aspects on selection of search-channels (online vs. offline) and search-platforms (mobile vs. PC) based on product types (Kim, Libaque-Saenz \& Park, 2019).

Empirical results and interpretation
The survey was realised in Latvia at the end of 2017 and beginning of 2018 on internet shopping in co-operation with company iMarketing, University of Latvia and Chamber of Trade and Commerce of Latvia. Survey was located on one the most popular platform of Latvia and randomly selected possible respondents were invited to answer questions included in the survey. 
It was ensured that each respondent can fill in the survey form only once. For those who have not filled the survey in two weeks it was sent repeated invitation and the third reminder was sent in two weeks once more to those persons selected to be included in the sample and who have not respondent.

All survey data were obtained in SPSS to ensure deep data analysis including use of multivariate data analysis and find out important aspects that could be found by use of several statistical analysis methods including methods of multivariate statistical analysis. Gathered survey data processing was conducted using cross-tabulations, using indicators of descriptive statistics: indicators of central tendency or location (arithmetic means, mode, median), indicators of variability (variance, standard deviation, standard error of mean, range), testing of statistical hypotheses, correlation analysis and analysis of variance - ANOVA.

A total of 2513 responses by respondents included in the sample were received; demographic profile of the sample is shown in Table 1.

More women than men participated in the study (but it corresponds also to gender distribution in the country). The most widely represented age groups ranged from 25 to 34 years, from 35 to 44 years and from 45 to 54 years, while the most respondents came from Riga and Riga region, while in other regions of Latvia the number of respondents was similar, which is similar to Internet usage in Latvia, compiled by the Central Statistical Bureau of Latvia.

In the study on Internet accessibility by CSB, it was discovered that residents of Riga and Pieriga region are the most active users of the Internet, followed by Kurzeme and Vidzeme, while the lowest proportion of Internet users is in Latgale.

\begin{tabular}{|c|c|c|c|}
\hline & & $\mathrm{N}$ & Percent \\
\hline \multirow{2}{*}{ Gender } & Female & 878 & 62.9 \\
\hline & Male & 518 & 37.1 \\
\hline \multirow{7}{*}{ Age group } & Under 18 & 26 & 1.8 \\
\hline & $18-24$ & 135 & 9.6 \\
\hline & $25-34$ & 357 & 25.3 \\
\hline & $35-44$ & 369 & 26.2 \\
\hline & $45-54$ & 324 & 23.0 \\
\hline & $55-64$ & 157 & 11.1 \\
\hline & $65+$ & 41 & 2.9 \\
\hline \multirow{4}{*}{ Region } & Riga and Riga region & 676 & 48.0 \\
\hline & Kurzeme district & 222 & 15.8 \\
\hline & Latgale district & 148 & 10.5 \\
\hline & Vidzeme district & 214 & 15.2 \\
\hline \multirow{6}{*}{$\begin{array}{l}\text { Last time when } \\
\text { shopping online }\end{array}$} & Zemgale district & 147 & 10.4 \\
\hline & In the last 30 days & 1343 & 63,41 \\
\hline & Two months ago & 281 & 13,27 \\
\hline & Three months ago & 108 & 5,10 \\
\hline & Six months ago & 113 & 5,34 \\
\hline & I do not remember & 273 & 12,89 \\
\hline
\end{tabular}

Source: Authors calculations based on survey in 2018, n= 2166
Table 1

Demographic profile of the sample of the survey in Latvia, in 2017 
Figure 1

Arithmetic means on respondent's evaluations on use of Internet in Latvia in 2017).
Table 2

Main Statistical Indicators on Female and Male Respondent's Evaluations on Use of Internet for Shopping in Latvia at the End of 2018
Most respondents of the survey last purchased a product or service on the internet over the last 30 days, but almost 400 respondents last bought something online six months ago or did not remember when, therefore to be more accurate from the further data analysis were excluded those who last bought something online six months ago and those who did not remember when was the last time they bought something online.

Since the emergence of the internet, time spending opportunities on the internet have only expanded, moreover, they depend on gender, age group, culture, national development level and many other factors. Figure 1 shows arithmetic means on respondent's evaluations on use of Internet in Latvia in 2017.

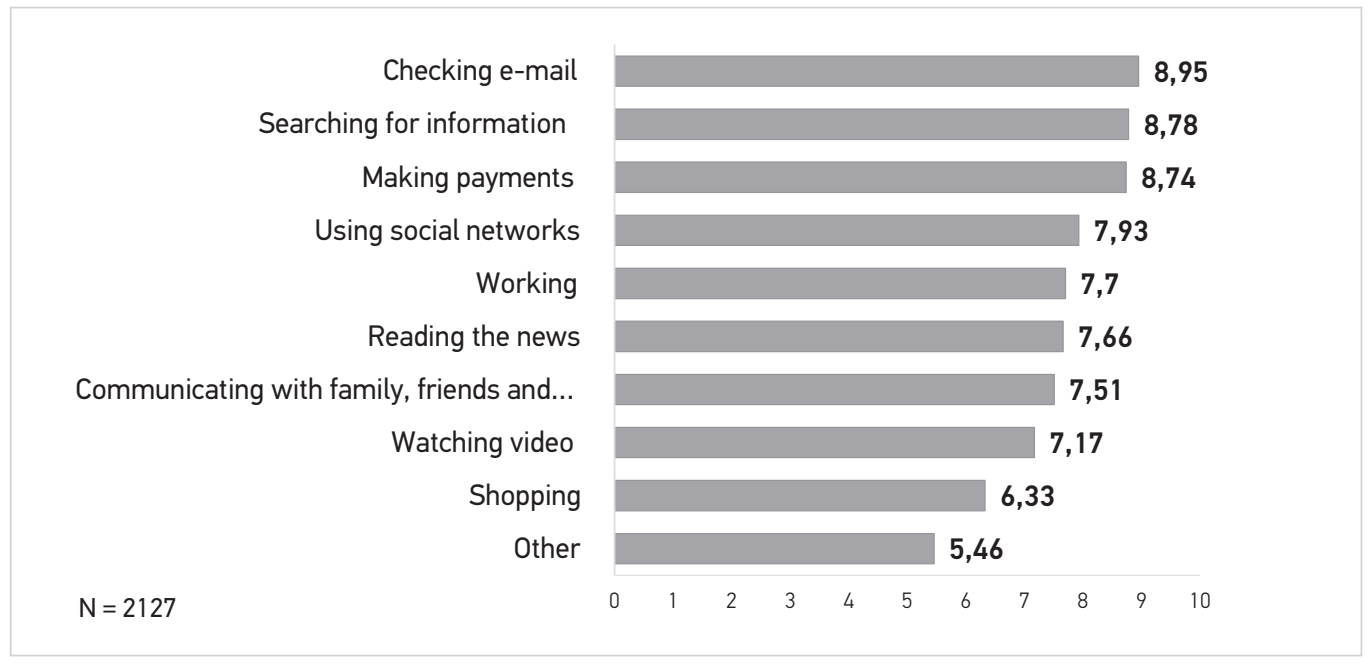

Source: Authors calculations based on survey in 2018, n=2166. Evaluation scale $1-10$, where 1 - do not use; 10 - use very often

Respondents have indicated that they use internet for a variety of activities, but the most popular ones are e-mail checking, information searching and making payment, but online shopping is the least popular activity in Latvia. Aside from purposes of use of internet other mentioned purposes were playing games, watching movies and TV series, using the internet for studies, listening to radio, music and reading books.

Although shopping online is not one of the most popular ways of using internet, for digital marketing managers and other professionals it is important to know if there are any differences between the gender ratings shown in Table 2.

\begin{tabular}{|l|c|c|c|c|}
\hline \multicolumn{1}{|c|}{ Gender } & N & Mean & Std. Deviation & Std. Error Mean \\
\hline Female & 907 & 7.00 & 2.670 & 0.089 \\
\hline Male & 536 & 6.81 & 2.670 & 0.115 \\
\hline
\end{tabular}

Source: Authors calculations based on survey in 2018, n=2166, Evaluation scale 1 - 10, where 1- do not use; 10 - use very often

As data of table 2 indicate - the evaluations by female and male respondents responses on use of internet for shopping in Latvia are very similar, but men's evaluations differences are greater which is indicated by bigger indicators of variability - standard error of mean, so for the purposes of clarification, an independent sample t-test was used to test statistical hypotheses on differences of arithmetic means on evaluations in the survey by female and male respondents on the use of internet - results are included in table 3 . 


\begin{tabular}{|c|c|c|c|c|c|c|c|c|c|}
\hline \multirow{3}{*}{$\begin{array}{l}\text { Statistical } \\
\text { indicators }\end{array}$} & \multirow{2}{*}{\multicolumn{2}{|c|}{$\begin{array}{l}\text { Levene's Test } \\
\text { for Equality of } \\
\text { Variances }\end{array}$}} & \multicolumn{7}{|c|}{ t-test for Equality of Means } \\
\hline & & & & & & & & $\begin{array}{r}95 \% \text { Cor } \\
\text { Interva } \\
\text { Differ }\end{array}$ & $\begin{array}{l}\text { fidence } \\
\text { of the } \\
\text { ence }\end{array}$ \\
\hline & $\mathrm{F}$ & Sig. & $\mathrm{t}$ & $d f$ & $\begin{array}{c}\text { Sig. } \\
\text { (2-tailed) }\end{array}$ & $\begin{array}{c}\text { Mean } \\
\text { Difference }\end{array}$ & $\begin{array}{l}\text { Std. Error } \\
\text { Difference }\end{array}$ & Lower & Upper \\
\hline $\begin{array}{l}\text { Equal variances } \\
\text { assumed }\end{array}$ & 0.036 & 0.849 & 1.305 & 1441 & 0.192 & 0.190 & 0.145 & -0.095 & 0.475 \\
\hline $\begin{array}{l}\text { Equal variances } \\
\text { not assumed }\end{array}$ & & & 1.305 & 1122.736 & 0.192 & 0.190 & 0.145 & -0.096 & 0.475 \\
\hline
\end{tabular}

Source: Authors calculations based on survey in 2018, n=2166, Evaluation scale 1 - 10, where 1- do not use; 10 - use very often

Independent Sample t-test of differences of responses revealed that there is no significant gender-related relationship in the use of internet for shopping evidenced by the level of significance which is 0.192 , therefore analysis of variance (ANOVA) was used to test statistical hypotheses on differences of mean evaluations by respondent's age group and the use of internet for shopping results are included in table 4.

\begin{tabular}{l|l|l|l|l|l|}
\hline & \multicolumn{1}{|c|}{ Sum of Squares } & \multicolumn{1}{|c|}{ df } & \multicolumn{1}{|c|}{ Mean Square } & F & Sig. \\
\hline Between Groups & 178.169 & 6 & 29.695 & 4.222 & 0.000 \\
\hline Within Groups & 10107.180 & 1437 & 7.034 & & \\
\hline Total & 10285.349 & 1443 & & & \\
\hline
\end{tabular}

Source: Authors calculations based on survey in 2018, n=2166, Evaluation scale 1 - 10, where 1- do not use; 10 - use very often

The analysis of variance indicates that evaluations by female and male respondents by age groups on use of internet for shopping do not differ statistically different with level of significance 0,000.

In order to test the relationship strength between the use of the internet for shopping and the region respondent is coming from, a correlation analysis was used - results are included in table 5.

\begin{tabular}{|c|c|c|c|}
\hline & & Internet Use for Shopping & Region \\
\hline \multirow{5}{*}{$\begin{array}{l}\text { Internet } \\
\text { Use for } \\
\text { Shopping }\end{array}$} & Pearson correlation & 1 & $-0.064^{*}$ \\
\hline & Level of Significance (Sig. (2-tailed)) & & 0.022 \\
\hline & Sum of Squares and Cross-products & 11017.094 & -298.765 \\
\hline & Covariance & 6.677 & -0.234 \\
\hline & $\mathrm{N}$ & 1651 & 1276 \\
\hline \multirow{5}{*}{ Region } & Pearson correlation & $-0.064^{*}$ & 1 \\
\hline & Level of Significance (Sig. (2-tailed)) & 0.022 & \\
\hline & Sum of Squares and Cross-products & -298.765 & 2773.450 \\
\hline & Covariance & -0.234 & 2.084 \\
\hline & $\mathrm{N}$ & 1276 & 1332 \\
\hline
\end{tabular}

${ }^{*}$ Correlation is statistically significant with the level of significance 0.05 (2-tailed)

Source: Authors calculations based on survey in 2018, $n=2166$, Evaluation scale 1 - 10, where 1 - do not use; 10 - use very often

Correlation analysis indicate that there is statistically significant relationship between the use of the internet for shopping and the region where respondent lives, what is indicated by the level of significance which is 0.022 .
Table 3

Independent Samples t-test on Significance of Differences of Responses by Female and Male on Respondent's Evaluations on Use of Internet for Shopping in Latvia in 2017

Table 4

Independent Samples Test with Analysis of Variance (ANOVA) on Significance of Differences of Responses by Age Groups on Respondent's Evaluations on Use of Internet for Shopping in Latvia in 2017

Table 5

Correlation Analysis of Respondents' Evaluation of Internet Use for Shopping and Region in Latvia in 2017 
Figure 2

Arithmetic means on respondent's evaluations on main activities on the internet using mobile phone in Latvia in 2017

\section{Conclusions}

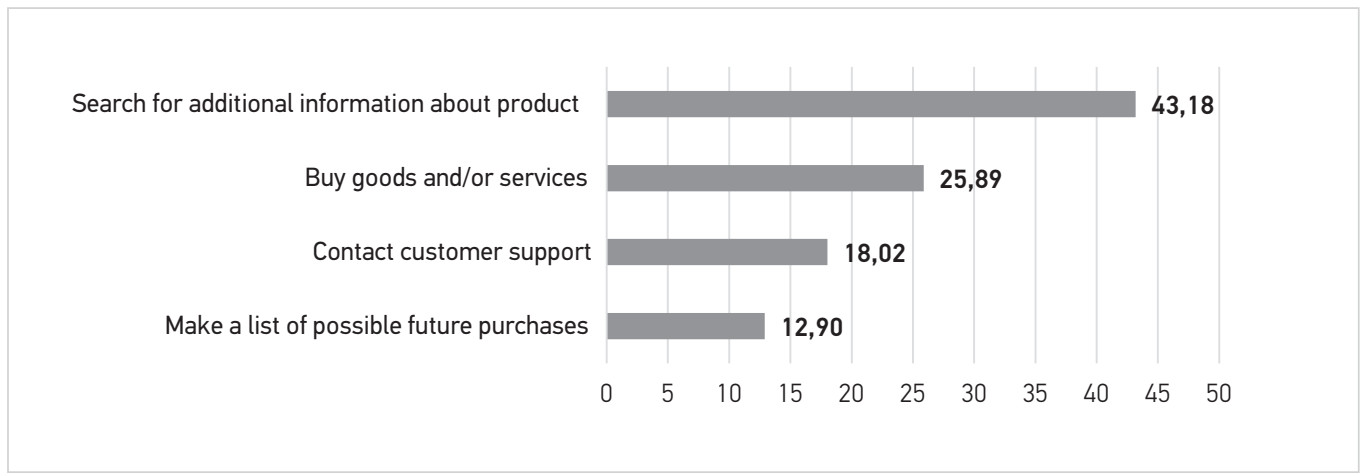

Source: Authors calculations based on survey in 2018, n=2166. Evaluation scale $1-10$, where 1 - do not use; 10 - use very often

More detailed analysis of other factors influencing internet-shopping have to be on investigation in many countries as several countries are developing in this aspect very fast and many countries in European Union have big challenges in catching up many developed counties world-wide to keep competitiveness of countries in European Union, including Latvia.

- Researchers world-wide in their academic research are investigating different aspects on development of internet-shopping including consumers attitudes and are suggesting practical steps for more efficient organisation of sales;

- Respondents from Latvia use internet mostly for checking e-mails, searching for information and making payments, not shopping online. Besides there are no significant relationship between gender and use of internet for shopping and between age group and use of internet for shopping. Correlation analysis indicated that there are statistically significant relationship between the region where respondent live and use of internet for shopping;

- Increase in internet shopping in Latvia is not increasing so fast as in other countries, customers use also mobile devices for shopping on internet; the use of mobile devices is becoming more attractive but not so often as in other countries; several local brads already having experience on internet shopping have big challenges in development of internet marketing;

- Customers highly evaluate previous personal experience and good references of relatives and friends (word of mouth) in use of respective brand and internet shop for internet shopping, but does not want to leave personal information (bank card information, personal code, etc.). Research has confirmed that marketing is influencing internet shop choice.

\section{References}

Castellacci, F. \& Vinas-Bardolet, C. (2019). Internet use and job satisfaction. Computers in Human Behavior, 90, 141-152. https://doi.org/10.1016/j. chb.2018.09.001

Chiu, Y. P. , Lo, S. K., Hsieh, A. Y. \& Hwang, Y. (2019). Exploring why people spend more time shopping online than in offline stores. Computers in Human Behavior, 95, 24-30. https://doi.org/10.1016/j. chb.2019.01.029

Clewley, N., Chen, S. \& Liu, X. (2009), Evaluation of the credibility of internet shopping in the UK, On- 
line Information Review, 33(4), 805-826.https://doi. org/10.1108/14684520910985738

Elms, J., de Kervenoael, R. \& Hallsworth, A. (2016). Internet or store? An ethnographic study of consumers' internet and store-based grocery shopping practices. Journal of Retailing and Consumer Services, 32, 234-243. https://doi.org/10.1016/j.jretconser.2016.07.002

Feng, S., Wong, Y. K., Wong, L. Y. \& Hossain, L. (2019). The Internet and Facebook Usage on Academic Distraction of College Students. Computers \& Education, 134, 41-49. https://doi.org/10.1016/j. compedu.2019.02.005

Fortson, B. L., Scotti, J. R., Chen, Y.-C., Malone, J. \& Del Ben, K., S. (2007). Internet Use, Abuse, and Dependence Among Students at a Southeastern Regional University. Journal of American College Health, 56(2), 137-144. https://doi.org/10.3200/ JACH.56.2.137-146

Francis, J. \& White, L. (2004), Value across fulfillment-product categories of Internet shopping, Managing Service Quality: An International Journal, 14(2/3), 226-234. https://doi. org/10.1108/09604520410528644

Fu, H., Manogaran, G., Wu, K., Cao, M. \& Yang, A. (2019). Intelligent decision-making of online shopping behavior based on internet of things. International Journal of Information Management, Available online 22 April 2019 in Science Direct. https:// doi.org/10.1016/j.ijinfomgt.2019.03.010

Grunert, K. \& Ramus, K. (2005), Consumers' willingness to buy food through the internet, British Food Journal, 107(6), 381-403.https://doi. org/10.1108/00070700510602174

Guillen-Royo, M. (2019). Sustainable consumption and wellbeing: Does on-line shopping matter? Journal of Cleaner Production, 229, 1112-1124.https:// doi.org/10.1016/j.jclepro.2019.05.061

Jiuan Tan, S. (1999), Strategies for reducing consumers' risk aversion in Internet shopping, Journal of Consumer Marketing, 16(2), 163-180.https://doi. org/10.1108/07363769910260515
Kim, E., Libaque-Saenz, C. F. \& Park, M.-C. (2019). Understanding shopping routes of offline purchasers: selection of search-channels (online vs. offline) and search-platforms (mobile vs. PC) based on product types. Service Business, 13(2), 305-338. https://doi.org/10.1007/s11628-018-0384-7

Lam, L. T. \& Lam, M. K. (2017). The association between financial literacy and Problematic Internet Shopping in a multinational sample. Addictive Behaviors Reports, 6, 123-127. https://doi. org/10.1016/j.abrep.2017.10.002

Lee, E., Temel, S. \& Uzkurt, C. (2016), The effect of consumers' innovation perception on internet usage behaviors, International Journal of Innovation Science, 8(2), 100-112. https://doi.org/10.1108/IJIS06-2016-007

Lim, Y. M. \& Cham, T.H. (2015). A profile of the Internet shoppers: Evidence from nine countries. Telematics and Informatics, 32(2), 344-354. https:// doi.org/10.1016/j.tele.2014.10.002

Malamud, O., Cueto, S., Cristia, J. \& Beuermann, D. W. (2019). Do children benefit from internet access? Experimental evidence from Peru. Journal of Development Economics, 138, 41-56. https://doi. org/10.1016/j.jdeveco.2018.11.005

Mudawi, M. S. E. (2005). The use of the internet and e-mail among Sudanese librarians: a survey report. Library Review, 54(6), 355-365.https://doi. org/10.1108/00242530510605485

Park, C. \& Jun, J. (2003), A cross-cultural comparison of Internet buying behavior, International Marketing Review, 20(5), 534-553.https://doi. org/10.1108/02651330310498771

Sharma, G., Bajpai, N., Kulshreshtha, K.,Tripathi, V. \& Dubey, P. (2019). Foresight for online shopping behavior: a study of attribution for "what next syndrome". Foresight, 21(2), 285-317.https://doi. org/10.1108/FS-11-2017-0069

Varma Citrin, A., Sprott, D., Silverman, S. \& Stem, D. (2000), Adoption of Internet shopping: the role of consumer innovativeness, Industrial Management \& Data Systems, 100(7), 294-300.https://doi. org/10.1108/02635570010304806 
About the authors

\section{SLOKA BIRUTA}

Dr.oec. Professor

University of Latvia

Fields of research

Multivariate data analysis,

marketing research, quantitative analysis

Address

Aspazijas bulv. 5 ,

Riga, LV - 1050

Phone. + 37129244966

E-mail: biruta.sloka@lu.lv

\section{ČIPĀNE KATE}

Cand. Mg.sc.admin., cand.for doctoral student

University of Latvia

Fields of research

Internet - shopping, marketing research, quantitative analysis

Address

Aspazijas bulv. 5,

Riga, LV - 1050

Phone. + 37129435194

E-mail: kate.cipane@lu.lv

\section{VOLVENKINS SERGEJS}

Dr.oec. Researcher, Manager iMarketing company

Fields of research Internet - shopping, marketing research, quantitative analysis

Address

Bērzaunes iela 7,

Rīga, LV-1039

Phone. + 37129435194

E-mail: rigalat@gmail:

sergejs.volvenkins@imarketings.lv 